\title{
Oceanography
}

CITATION

Greene, C.H. 2006. Review of Down to the Sea for Science: 75 Years of Ocean Research,

Education, and Exploration at the Woods Hole Oceanographic Institution, by V. Cullen. Oceanography 19(1):189-191, http://dx.doi.org/10.5670/oceanog.2006.105.

DOI

http://dx.doi.org/10.5670/oceanog.2006.105

COPYRIGHT

This article has been published in Oceanography, Volume 19, Number 1, a quarterly journal of The Oceanography Society. Copyright 2006 by The Oceanography Society. All rights reserved.

USAGE

Permission is granted to copy this article for use in teaching and research. Republication, systematic reproduction, or collective redistribution of any portion of this article by photocopy machine, reposting, or other means is permitted only with the approval of The Oceanography Society. Send all correspondence to: info@tos.org or The Oceanography Society, PO Box 1931, Rockville, MD 20849-1931, USA. 
Important points are always presented in bullet form. This is acceptable in a PowerPoint presentation, but it is tedious and overdone in this book. Few readers, myself included, are going to wade through his three-page, 53-bullet "summary of what environmental end-users might need." The information is important and logically summarized, but the presentation makes for slow reading.

\section{Down to the Sea for Science 75 Years of Ocean Research, Education, and Exploration at the Woods Hole Oceanographic Institution}

\author{
By Vicky Cullen, Woods Hole \\ Oceanographic Institution, 2005, 184 \\ pages, Hardcover, \$25 US
}

\section{REVIEWED BY CHARLES H. GREENE}

Since its beginning, the Woods Hole Oceanographic Institution (WHOI) has been the quintessential American oceanographic research institution. Although WHOI was not the oldest American institution dedicated to ocean research, not even the most senior within the town of Woods Hole, its history during the past century has been one of constantly breaking new ground and setting new trends for the world's ocean research community. What is it that set this groundbreaking and trendsetting institution apart from the other oceanographic research institutions that came into existence during the past century? The answer to this question can be found in Vicky Cullen's richly illustrated history of WHOI entitled Down to the Sea for Science.

Down to the Sea for Science was written to commemorate WHOI's $75^{\text {th }}$ an- niversary. Today, it is remarkable to contemplate how far WHOI and American oceanography have come during those 75 years and how closely intertwined are the histories of both. Although WHOI was founded in 1930, its roots, as well as those for American oceanography as we know it today, can be traced back to the $19^{\text {th }}$ century. Vicky Cullen does a superb job of chronicling in words, illustrations, and photographs how the small village of Woods Hole evolved from the modest home of the U.S. Bureau of Fisheries' first permanent field station in 1885 to what is today one of the most renowned centers of ocean science in the world.

During the decade leading up to the founding of WHOI, two prominent marine biologists, Frank Lillie of the University of Chicago and Henry Bigelow of Harvard, set into motion the events that would alter the history of oceanography. Lillie, considered "the founding father of WHOI," was the driving force behind these events, using his formidable lobbying skills to sway the scientific policies of the federal government while
Curtis D. Mobley (curtis.mobley@ sequoiasci.com) is Vice President and Senior Scientist, Optical Oceanography, Sequoia Scientific, Inc., Bellevue, WA, USA.

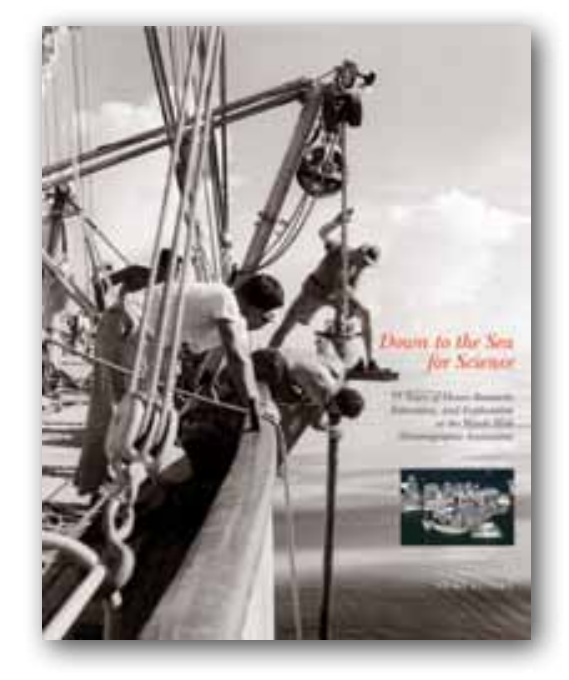

simultaneously securing unprecedented private support for oceanography from the Rockefeller Foundation. As a result of Lillie's efforts, the National Academy of Sciences formed a Committee on Oceanography, chaired by Lillie, which was charged with creating a vision for the future of oceanography in the United States. Under Bigelow's guidance, as secretary, this Committee produced a final report that was not only influential in steering the future direction of American oceanography, but also instrumental in the establishment of WHOI.

"The establishment of a well equipped oceanographic institution on the Atlantic coast" was the first recommendation made by the Committee on Oceanography. With generous support from the Rockefeller Foundation, this 
recommendation quickly became a reality, and WHOI was born. Bigelow was recruited from Harvard as WHOI's first director, a position he would hold for the initial decade of the new institution's existence. Although "quiet, modest, and unassuming," Bigelow made his mark on the future development of WHOI and American oceanography in general. His interdisciplinary approach to oceanography, as evidenced by his earlier physical and biological studies of the Gulf of Maine, was adopted not only at WHOI, but foreshadowed its subsequent adoption at the Scripps Institution of Oceanography (SIO) and other prominent schools of oceanography throughout the United States.

Bigelow's student and protégé, Columbus Iselin, took over the reigns at WHOI in 1940 and oversaw the war-time boom years between 1941 and 1945, when the Institution made the transition from a small-scale, largely summer-time venture focused on basic research to a large-scale, year-round operation doing applied Navy research. The expansion in staff and facilities associated with the Second World War led to an uncertain period afterwards as both the Navy and WHOI readjusted to a world at peace. This rocky transitional period was eased somewhat by the establishment of the Office of $\mathrm{Na}$ val Research and National Science Foundation, the first federal funding agencies in the United States committed to supporting scientific research.

In 1950, Iselin stepped down as director and was replaced by Edward Smith, who served until 1956. WHOI continued to grow during Smith's tenure; however, the relationship between the Institution and its director was an un- easy one. Smith's military background did not lend itself to WHOI's "can do but unstructured atmosphere." In many respects, Iselin continued to serve as WHOI's de facto director, a situation that was formalized when he returned to the directorship from 1956 to 1958 . This was a critical two-year period for WHOI as it coincided with the International Geophysical Year (IGY) and Russia's two Sputnik launches. American oceanography would be strongly impacted by each of these events, and it was to WHOI's advantage that a spokesperson as highly regarded as Iselin was at the helm.

In June 1958, Iselin passed the directorship on to Paul Fye. Spurred by President John Kennedy's vision “to tap the ocean depths," oceanography in the United States entered its golden age. During Fye's tenure as director, from 1958 to 1977, WHOI's operating budget increased nearly tenfold and its staff doubled in size. To support its enhanced operations and accommodate its enlarged staff, WHOI's research fleet and onshore facilities grew at an unprecedented rate. Larger, more capable research vessels, such as Atlantis II, Knorr, and Oceanus, joined the Institution's fleet, as did the first civilian deep-submergence vehicle, Alvin. Onshore, the village of Woods Hole could no longer keep pace with WHOI's demands for more space, so the new Quissett Campus was acquired and construction of new laboratories began. There were many other notable advances at WHOI during the Fye administration, including the acceptance of women participating on oceanographic cruises and the establishment of two new programs that were influential in the Institution's sub- sequent development: the Joint Program for graduate education, offered with the Massachusetts Institute of Technology (MIT), and the Marine Policy and Ocean Management Program.

When Fye stepped down as director after 19 years in 1978, WHOI was beginning to feel the tightening of federal agency purse strings as the golden age of oceanography gradually came to a close. John Steele arrived from the Marine Laboratory in Aberdeen, Scotland to become WHOI's fifth director. During his administration from 1978 to 1989 , the pace of growth at WHOI declined, but there was a focusing of the Institution's intellectual and scientific talents. As Bob Gagosian, WHOI's associate director at the time, observed in the 1989 annual report, "Competition for federal funding sources dramatically increased as the decade came to a close. As a result, our Scientific and Technical staffs have had to sharpen their focus and spend more time trying to market and sell their science." Although staff members throughout the Institution responded well to the challenge of increased competition for federal funding, perhaps no individual and group were better prepared to market and sell their science than Bob Ballard and WHOI's Deep Submergence Laboratory (DSL). Using Navy support to pioneer the development of deep-sea vehicles, Ballard and his DSL colleagues captured the public's imagination with high-profile expeditions to the Titanic and other sites of historical and scientific interest. In many respects, the DSL's success during the 1980s and 1990s promoted national and international interests in deep-sea technology that are central to today's major initiatives in 
ocean observing systems and ocean exploration.

In 1989, Craig Dorman, a former Navy admiral, succeeded Steele as director. Dorman was a graduate of the MIT/WHOI Joint Program and developed a reputation within the Institution as a hands-on and supportive director. With Dorman's encouragement, WHOI formed new international alliances and strengthened its relationships with industry and various federal agencies. Unfortunately, WHOI weathered an aggressive federal audit, a problematic refit for R/V Knorr, and a difficult transition to a computerized financial system during Dorman's tenure as director. The role that these events played in Dorman's decision are not detailed by Vicky Cullen, but Dorman left WHOI in 1993 after only four years as director.

Bob Gagosian, WHOI's current director, replaced Dorman in 1993. Gagosian moved up the ranks at WHOI from Assistant Scientist to Director over a period of 21 years. This long relationship with WHOI presumably provided him with the experience and resiliency necessary to steer the Institution through the turbulent, but exciting times oceanography has faced over the past 12 years. Vicky Cullen does not provide much detail here, preferring instead to focus her story on the events and people whose stories are complete. I assume that we will have to wait for the Institution's $100^{\text {th }}$ anniversary before we learn more about Gagosian and WHOI in the new millennium.

After reading Down to the Sea for Science, I found myself reflecting on what it was that set WHOI apart from its peer institutions during the first 75 years. WHOI was certainly not the oldest institution dedicated to marine research in the United States, with the Marine Biological Laboratory (MBL) in Woods Hole, the University of Washington's Friday Harbor Laboratories (FHL), and SIO all celebrating their centennials prior to WHOI's $75^{\text {th }}$ anniversary. Given the great rivalry that developed between WHOI and SIO over the past 75 years, I found a comparison of the two institutions' early histories quite revealing (see Oceanography Vol. 16, No. 3, 2003 for a centennial review of SIO's history). Despite it seniority in age, SIO did not begin to emerge as the great interdisciplinary oceanographic institution it is today until after Harald Sverdrup became its third director in 1936. Prior to 1925, SIO was called the San Diego Marine Biological Institution, and it was primarily dedicated to the study of marine biology in the same tradition as the MBL and FHL. In 1924, T. Wayland Vaughan, a marine geologist by training, became the San Diego Marine Biological Institution's second director and succeeded in changing its name to SIO the following year. Vaughan had a clear vision of what it takes to make a great interdisciplinary oceanographic institution. This is revealed in an excerpt from one of his correspondences with Bigelow when both were members of the Committee on Oceanography:

From the last paragraph of your [January 17] letter it appears to me that you are still looking on oceanography as an adjunct to biology. I would rather turn it around and look on marine biology as an adjunct to oceanography. You have been [led] to study the ocean primarily from a biological motive, whereas my motive was primarily a geological one. Since I am in the oceanographic game I should combat the consideration of the sea as an adjunct to geology no matter how important geology may be... I think that the ocean should be studied as a thing for itself and as one of the most important parts of the earth. ${ }^{1}$

After reading this quote from Down to the Sea for Science and reviewing the SIO centennial issue of Oceanography, I conclude that one of the great ironies in the early history of American oceanography is the strong influence that Vaughan, the Director of SIO, had in shaping the future direction of WHOI. Had Vaughan received a comparable share of the Rockefeller funding for SIO, then perhaps the histories of these two great oceanographic institutions may have been reversed, and WHOI would have found itself playing catch up with its west coast rival at the dawn of the Second World War expansion in oceanography. Visionary leadership, political influence, and timing were all key ingredients in shaping American oceanography during the $20^{\text {th }}$ century. WHOI's good fortune in all three enabled it to become the groundbreaking and trendsetting institution it is recognized as today.

Charles H. Greene (chg2@cornell.edu) is

Director, Ocean Resources and Ecosystems Program, Department of Earth \& Atmospheric Sciences, Cornell University, Ithaca, NY, USA.

' Reproduced in Down to the Sea for Science (p. 12-13) from H.B. Bigelow correspondence, Special Subjects 1913-1930, HUG4212.10, Harvard University Archives. 